\title{
Migration Structure of Russian Intellectuals within the Academic and Industry Environment
}

\author{
Alexander Leonardovich Aref'ev ${ }^{1}$ \\ Franz Edmundovich Sheregi2 \\ ${ }^{1}$ Center for Sociological Research of the Ministry of Education and Science of the Russian Federation, Moscow, Russian Federation \\ Email: alexander.arefiev@gmail.com \\ ${ }^{2}$ National Research Nuclear University (MEPhl), Moscow, Russian Federation \\ Email: f-sheregi@inbox-ru
}

\section{Doi:10.5901/mjss.2015.v6n4s4p39}

\section{Abstract}

The article, based on a statistical analysis and the results of sociological research conducted by and under supervision of the authors of the article in the Center for Social Forecasting and Marketing for the period covering 2005-2014, focuses on the problems of migration and "brain drain" from Russia. The process, which is causing considerable damage to the Russian economy, is exemplified in the form of external emigration by scientists and university professors to the more economically developed countries, and in the form of internal migration, when researchers and intellectuals exchange scientific pursuits for business and commerce. There is also the continued relocation of researchers to different regions of Russia (mainly for family reasons), and (to a lesser extent) emigration to countries of the former Soviet Union, predominantly for ethnic reunion. The most aggravating trend is the growth of emigration attractiveness among Russian students and university graduates. Among those leaving to study abroad, the majority are not going to return to Russia. The authors identify the main causes of these phenomena to be as follows: low salaries for young researchers, accommodation problems, low chances of buying a house or a flat, poor facilities and a lack of modern equipment and a suitable scientific environment, lack of perspectives and the predictability of an academic career, low social prestige of the profession of a researcher and the lack of effective state measures aimed at improving the situation in Russian science fields and facilities. The authors view the following as urgent: creating better working conditions for Russian researchers, academic production ramp-up demanded by domestic producers, establishment of non-state funds to support science with the profit received by economic monopolies.

Keywords: migration, researchers, scientists, intellectual work, brain drain.

\section{Introduction}

Migration statistics, in Russia, are far from perfect and a large proportion of intellectual emigration is ignored. Due to incomplete statistics, the findings of the researchers who studied migration often vary. Among the most distinguished are the works of L.L. Rybakovskii (Transformation of Migration ..., 2009), I.G. Dezhina (Dezhina, 2002, 2006), E.F. Nekipelova (Nekipelova, 1998), J.A. Zayonchkovskaya (Zayonchkovskaya, 2004), O.A. Ikonnikova (Ikonnikova, 1993). Therefore the authors view a comparative analysis of different positions and by contrasting the data of sociological studies pursued in Russia as beneficial and interesting for anticipating the future.

After the collapse of the Soviet Union in the early 1990s and the subsequent economic crisis there was a rise in emigration among intellectuals including researchers and university professors. This trend did not contribute much to the detriment of the economy primarily due to having only outdated technologies at its disposal which could not be modernized on its own basis and which intellectual potential was not relevant for it.

During the 2000s there was a period of stabilization in some sectors including the defense industry that allowed the Russian Government to definitively state the modernization tasks required through the cooperation of innovation intentions of leading industrial companies with the scientific potential of research organizations and universities. The support of this cooperation implies, on the part of the government, not only administrative but also financial assistance for technological platforms created by cooperating agents. ${ }^{1}$ This became possible thanks to surveys conducted by

1 This position is reflected in the Government Decisions from 9 April, 2010 №218 "On Measures of Government Support for Developing Cooperation of Higher Education Institutions and Organizations Realizing Complex Projects for the Building of High-Technology Production" and №219 "On Measures for Attracting Leading Researchers in Russian Higher Professional Education Institutions". 
sociologists in the middle of the 2000s which highlighted the inequalities in the stabilization of scientific work and the appearance of the elite stratum shaping opinion about the stability of research institutions in Russia that veiled the "scientific impotence" of many research organizations. As a result, many scientists withheld the level of their dissatisfaction with regards to salary levels and their attitudes regarding changing fields to the business or commerce sector or emigration. At the same time, "the elite" of research organizations were quite satisfied with their material conditions and did not want to take the trouble of undertaking scientific work in their organizations. The reasons for this are understandable if we pay attention to the profiles of persons with the highest incomes in the field of science (Dezhina, 2006, p. 175):

- Researchers receiving foreign grants whose percentage is moderately growing thanks to the development of outsourcing, especially in computer sciences and applied natural sciences;

- Directors of research organizations and top managers;

- Scientific entrepreneurs involved in business innovation in addition to scientific work;

- Advisers and analysts involved in expert work with different governmental and political bodies (mainly social scientists);

- Some of the researchers are involved in the process of "pendulum migration" between different countries.

\section{Migration and Emigration of Russian Researchers}

Currently, in the Russian science community, there are 26800 Doctors of Sciences (Indicators of Science, 2014, p. 56) while, in the United States alone, there are 16000 Doctors of Sciences who originated from the former Soviet Union. The demographic crisis in the Russian science community (less than one third of researchers fall into the most productive category band, 30-50 year-old, and a quarter of Doctors of Sciences are older than 70) may acquire an irreversible characteristic. It is not accidental that only $1 \%$ of respondents treat the scientific profession with respect in contrast with 56\% in the United States (Science and Engineering indicators, 2010, pp.10-16).

Brain drain has become typical among young scientists. One of the surveys dated to the middle of the 2000s (Dezhina, 2006, p. 177) and aimed at researchers in the institutions of the Russian Academy of Sciences has confirmed the opinions of many experts, that during the last 10-15 years the group most oriented towards emigration have been young scientists. It has also been found that there was a considerable volume of people planning to leave among junior personnel: $15 \%$ of junior researchers and $14 \%$ of postgraduate students.

The estimations of researchers' migration flow have serious biases because indicated motives and terms of leaving do not always correspond with the actual ones. This is why there is a need to resort to approximate data presented by national and foreign statistical agencies. According to the data of migration services for economically developed countries from January 2004 to January 2008, 218230 people have left Russia to live permanently in Europe, North America and Australia. During the same time frame the inflow of Russians to Belgium, Norway and the Czech Republic increased by 24600 people with $14 \%$ of them having been naturalized. One fifth of the emigrants were young people in the 20-24 age range and 57630 people in the 35-40 range. (Transformation of Migratory Processes in the Post-Soviet Union, 2009, p.8).

From those who have emigrated 13410 have taken highly qualified jobs within big companies in the UK, Poland, Greece, France, Italy and Spain; 630 are involved in fundamental research; and 6860 work in high-technology industries. 5220 immigrants from Russia have taken top-management positions in Hungary, Switzerland and the UK. Furthermore, according to UN data, in 200811000 immigrants from Russia have received refugee status and residence in other countries. In 2007 this number amounted to 2010 people. Two third of the refugees (7720 people) live in Poland, Austria, France and Belgium, 1810 people in Norway, Sweden and Germany, with the rest in the US, Canada, Australia and New Zealand.

The third recognized group of Russian emigrants consists of those people who went abroad to study. Annually around 30000 people leave Russia with training visas for the UK and 5000 for Germany, France, Canada and Australia (fig. 1). More than 63 thousand Russians were enrolled at various tertiary level programs in 2012 (OECD, 2014). Around $30 \%$ do not return to Russia. 


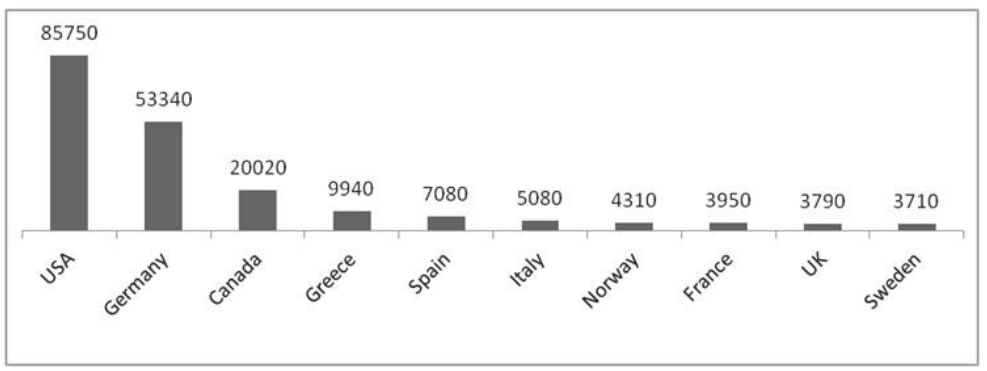

Figure 1 - Destination countries of Russian emigrants, 2004-2008, number of people

Among the emigrants from Russia are many professionals (39\%) with higher education. Their professional structure is presented in fig. 2 along with motives for emigration in fig. 3.

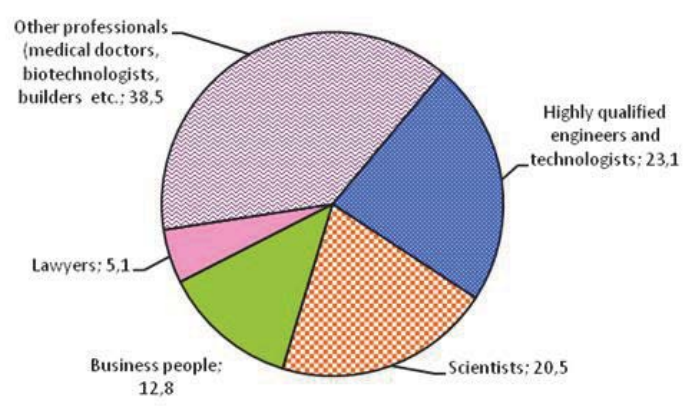

Figure 2 - Professional structure of Russian emigrants with higher education, $\% 2$

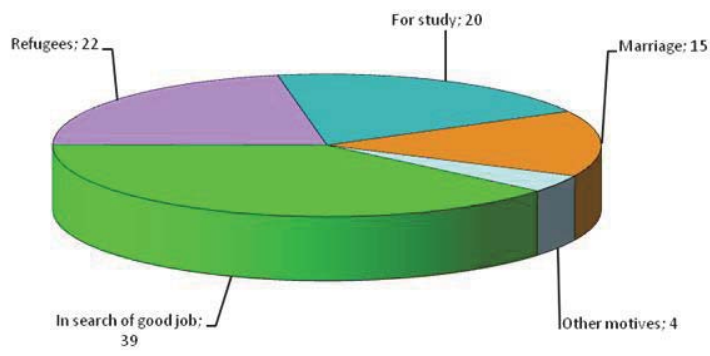

Figure 3 - Motives for leaving Russia, \%

Emigration from Russia is on the decrease but it is still considerable. In a report by S. Stepashin the President of the Accounting Chamber the number 1.25 million people was voiced as an approximate figure. This is the number of people who have emigrated from Russia over the last 10 years (Shapovalova, 2014). Based on this figure the number of emigrants from Russia in 2009-2011 has been calculated (see fig. 4).

$2100 \%$ - the total number of emigrants with higher education and accounting for $39 \%$ of the total number of all Russian emigrants. 


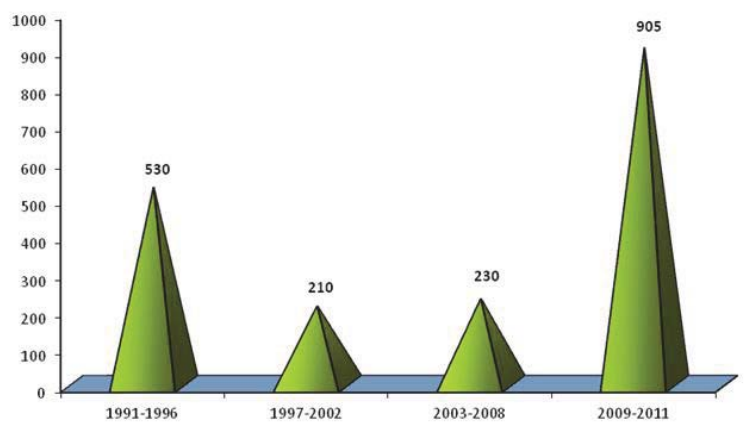

Figure 4 - Dynamics of emigration from Russia, thousand people

Keeping aside the retirement group, which for researchers does not usually mean the end of scientific work, the more relevant group demographic are that of professional and geographic migrations. As a generalized rule, this is a change to business, moving to other regions of Russia, departure abroad because of long-term contracts, emigration to Post-Soviet countries and to economically developed countries. This migration structure is confirmed in the course of surveys by researchers themselves based on the observations of their colleagues' behaviour. As the results of an expert survey conducted by the Centre of Social Forecasting and Marketing have shown, the researchers' motives for moving to other regions of Russia are objective and related to family circumstances, mainly marriage. This reason, in addition to ethnic reunification, also urges some researchers to emigrate to Post-Soviet countries.

Departure abroad because of long-term contracts is dictated, generally, by two reasons: low salaries in Russian research organizations and deteriorating conditions for fundamental research.

The probability of staying abroad, in the case of a long academic trip and a suitable contract is low for teachers over 50, managers and those who are not planning a job change (see Table. 1). The probability of remaining abroad is high among teachers under 30 years old, those who are not employed as top managers and those who are careertransition oriented.

Table 1. Age Based Distribution of Russian Teachers' Probability of Relocating and Staying Abroad and the chance of receiving a Profitable Job Offer, \%

\begin{tabular}{|l|c|c|c|c|c|c|c|}
\hline \multirow{2}{*}{ Probability Degree } & \multicolumn{7}{|c|}{ Age } \\
\cline { 2 - 9 } & under 26 & $26-30$ & $31-40$ & $41-50$ & $51-60$ & $61-65$ & over 65 \\
\hline High Probability & 27,4 & 22,5 & 12,6 & 8,6 & 2,3 & 6,8 & 1,3 \\
\hline Low Probability & 37,9 & 37,4 & 32,6 & 27,3 & 21,7 & 13,7 & 3,9 \\
\hline No Chance & 17,9 & 21,2 & 32,6 & 42,2 & 54,3 & 57,5 & 70,1 \\
\hline Do not have an unambiguous opinion & 16,8 & 18,9 & 22,2 & 21,9 & 21,7 & 22,0 & 24,7 \\
\hline Total & 100 & 100 & 100 & 100 & 100 & 100 & 100 \\
\hline
\end{tabular}

It is quite logical to assume that many of the researchers, who plan to stay abroad for a long period, have nothing but its "virtual" representation, therefore, the majority of hopes for emigration are delusional in nature.

\subsection{Migration Motives}

The results of a nationwide survey of 1500 university professors and 2000 researchers of academic and industrial research organizations conducted in 2014 by the Center for Social Forecasting and Marketing suggest that Russian intellectuals' migration follows five different vectors:

1. A change of job, aimed at either a promotion or salary increase in a similar institution or a producing company.

2. A shift to a commercial business for a higher salary.

3. Relocation to another region in search of better working conditions, or for family reasons.

4. Migration to a former USSR country, mainly due to family circumstances or ethnic grounds. 
5. Emigration abroad, mainly due to career reasons or for better perspectives for children $(11.6 \%$ of researchers want their children to receive vocational training in one of the countries outside the former Soviet Union, while $14.3 \%$ want their children to live in one of the countries outside the former Soviet Union).

Since intellectuals do not usually relinquish research at pension age, it is not retirement, but professional and territorial migration which significantly reduces the number of working scholars. Migration may take one of the following forms: leaving an academic career for commerce; relocation to another region within Russia; relocation outside Russia on a long-term contract; emigration to the countries within the Commonwealth of Independent States (CIS); emigration to developed countries. A similar migration pattern for scientists and researchers is confirmed by sociologists based on their surveys and observations (see Table. 2).

Table 2. Opinion Survey on Reasons for Russian Scholars' Migration \%

\begin{tabular}{|l|c|c|c|c|c|}
\hline & \multicolumn{4}{|c|}{ Migration types } \\
\hline Reasons for Migration & $\begin{array}{c}\text { Occupational } \\
\text { change to the } \\
\text { business sector }\end{array}$ & $\begin{array}{c}\text { Relocation } \\
\text { within the } \\
\text { country }\end{array}$ & $\begin{array}{c}\text { Contractual long } \\
\text { term employment } \\
\text { abroad }\end{array}$ & $\begin{array}{c}\text { Emigration } \\
\text { to CIS }\end{array}$ & $\begin{array}{c}\text { Emigration to } \\
\text { economically } \\
\text { developed countries }\end{array}$ \\
\hline Low salaries for researchers in Russia & $\mathbf{8 4 , 7}$ & 18,7 & $\mathbf{6 2 , 9}$ & 12,2 & $\mathbf{6 3 , 3}$ \\
\hline Poor IT support for research projects & 13,9 & 6,0 & 23,8 & 1,5 & 19,8 \\
\hline Slow manufacturing application of new academic innovations & 23,1 & 4,2 & 20,2 & 1,6 & 22,1 \\
\hline Property Rights Insecurity for Intellectual Products & 22,3 & 2,7 & 18,2 & 1,6 & 24,2 \\
\hline Lack or absence of career perspectives & 36,6 & 9,6 & 27,5 & 3,1 & 28,8 \\
\hline Worsening conditions for practicing fundamental science & $\mathbf{3 0 , 7}$ & 6,5 & $\mathbf{3 4 , 4}$ & 2,8 & 35,1 \\
\hline Low prestige of scientific work & $\mathbf{5 2 , 6}$ & 6,5 & 29,6 & 3,8 & 32,3 \\
\hline Obscure life perspectives & 42,7 & 6,8 & 26,9 & 3,6 & 31,1 \\
\hline Limited access for young talented researchers from remote & 18,4 & 13,1 & 20,2 & 1,8 & 20,5 \\
\hline areas to scientific research centers & 6,3 & 3,4 & 25,4 & 1,2 & 21,4 \\
\hline Limited opportunities for contact with foreign colleagues & 10,8 & 4,2 & 17,1 & 3,0 & 30,8 \\
\hline Instability of the political situation in Russia & 5,1 & 4,5 & 10,0 & 1,9 & 20,5 \\
\hline Threat of social disorders & 4,1 & 2,3 & 7,6 & 1,5 & 17,7 \\
\hline Fear of strengthening authoritarian methods of government & 21,8 & 6,1 & 15,8 & 3,4 & 32,7 \\
\hline Concern for children's future & 23,4 & 6,8 & 12,5 & 2,4 & 17,3 \\
\hline Unemployment threats & 17,9 & 5,1 & 19,4 & 4,0 & 28,1 \\
\hline Instability of the economic situation in Russia & 27,0 & 6,7 & 25,9 & 3,5 & 22,0 \\
\hline Poor of facilities in research institutions & 17,1 & $\mathbf{2 6 , 6}$ & 7,9 & $\mathbf{2 4 , 7}$ & 12,5 \\
\hline Family Commitments & 1,5 & 12,4 & 3,0 & $\mathbf{2 3 , 0}$ & 13,5 \\
\hline Ethnic re-union & & & & \\
\hline
\end{tabular}

The motivations for researchers to relocate to other regions of Russian are intrinsic, and it is caused, typically, by family commitments i.e. marriage. This reason, as well as ethnic reunion motivates some researchers to also emigrate to countries of the former Soviet Union. Since this will occur naturally it can be surmised that it has less direct impact on the brain drain phenomenon.

A study conducted by the Center for Social Forecasting and Marketing in 2014, demonstrated that $7.8 \%(30,700)$ of scholars are potential emigrants and when interviewed admitted that were they to receive a good job offer from a foreign employer during their temporary contract abroad, they would consider staying "for a long time" or indefinitely. Another $21.3 \%$ consider the course of such events to be unlikely; though do not eliminate the idea completely. $47.7 \%$ of researchers do not consider such situations at all, and $23.2 \%$ do not have a clear-cut stand on this matter.

Emigration is viewed as probable by $9.5 \%$ of fundamental scientific researchers, $8.1 \%$ of scholars in applied sciences and $6.7 \%$ in development. Emigration is viewed as probable by $10.4 \%$ of scholars employed by the Russian Academy of Sciences, $6 \%$ in other academies, $6.8 \%$ in industrial organizations and $5.9 \%$ in higher educational institutions.

Relocation abroad by researchers on long-term contracts is caused mainly by two distinct reasons: low salaries for Russian academia and poor facilities to pursue fundamental scientific research.

Most variable is the Russian researchers' motives for changing to business sectors and/or emigrating to economically developed countries. A hierarchic sequence of the motives looks as follow: In the first case regarding a shift to the business sector then; low salary $\Rightarrow$ low prestige of scientific work $\Rightarrow$ uncertainty of life prospects $\Rightarrow$ lack of prospects for professional growth $\Rightarrow$ deteriorating conditions for fundamental research; and in the second case related to emigration; low salary $\Rightarrow$ deteriorating conditions for fundamental research $\Rightarrow$ anxiety about children $\Rightarrow$ low prestige of scientific work $\Rightarrow$ uncertainty of life prospects $\Rightarrow$ instability of the political situation in Russia. 
Listed among the major reasons for scientific and academic personnel to depart abroad are: low salaries for young scientists, lack of accommodation and prospects to acquire it, lack of modern equipment and conditions for research, lack of prospects and uncertainty of a scientific career, low prestige of scientific profession in society, lack of adequate measures on the part of the government to improve the situation in the Russian science sector.

One of the measures initiated by the Russian Government in the late 2000s was called "Conducting Research by Teams under the Guidance of Invited Researchers" and was a part of a wider federal programme called "Scientific and Academic Personnel of Innovational Russia". This programme was aimed at supporting Russian scientists who wanted to return to Russia from abroad. The goal of this measure was to develop a cooperative programme with Russian scientists permanently or temporarily working abroad; attaching them to Russian science and education; using their experience, skills and knowledge to aid in the development of the Russian science, education, and high technologies. The result of this programme has been partly realized in the Skolkovo project aimed at contributing to the innovative aspirations of the Russian economy. The effectiveness of the project will only be clear in 10-15 years when its scientific results are converted into innovational products.

The evident detriment to the potential of Russian science is caused by the international migration of graduates and young researchers (aged 35 and younger). Furthermore, recently, emigration is increasingly replaced by gradual and latent forms of migration that, in absence of strict requirements for filling in papers for departure, leads to a distorted picture of the real scale of emigration. Its considerable impact remains ignored by official statistics.

\subsection{The Negative Impact of the "Demographic pit" and Students' Emigration}

In addition to migration of researchers and decreasing inflow of young people, the "demographic pit" plays a negative role in the reproduction of scientific personnel which creates a shortage of personnel in general and decreases the number of students in professional education institutions. Beginning from 2004, the overall population in the 14-30 age range has been drastically decreasing and this process promises to be long-term. It is not possible to compensate for the decrease through migratory exchange (The transformation of migration processes within the territory of the former Soviet Union, 2009 , p. 15). This decrease in the general number of $15-29$ year-olds will lead to drastic reduction in the total of economically active population by $12,8 \%$, from $37,2 \%$ in 2007 to $24,4 \%$ in 2021 (see fig. $5-6$ ). The total population in the 14-30 age band as estimated on 1st January 2009 was 37 million.

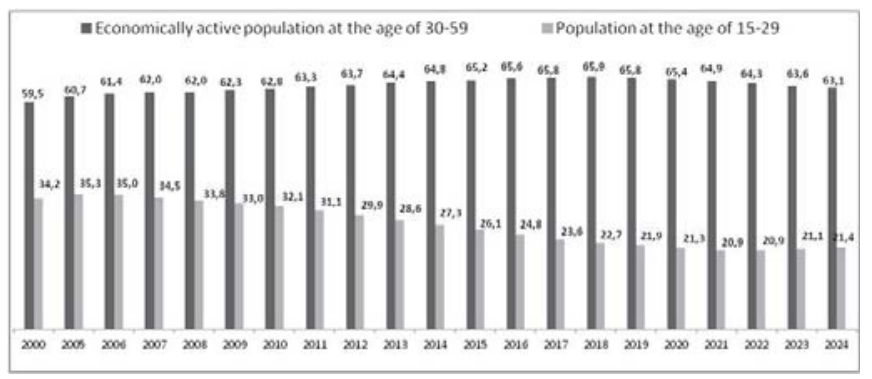

Figure 5 - Number of economically active population between the ages of 30-59 and population levels for the 15-29 age range, million people

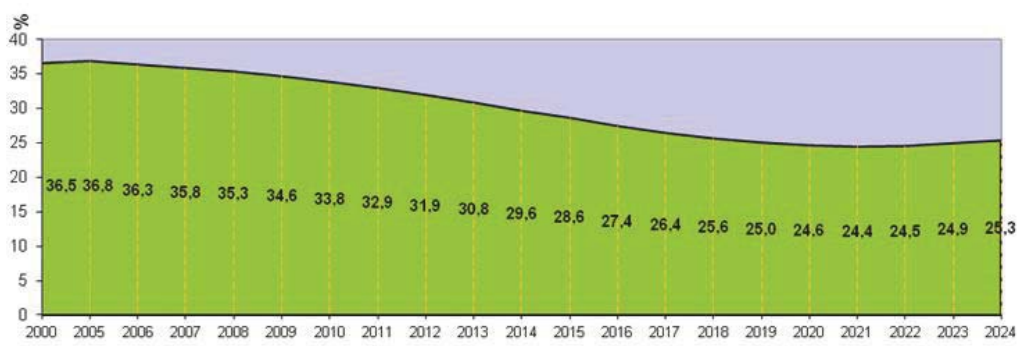

Figure 6 - Percentage of the population at the age of 15-29 in the cohort of 15-59 year-old 
According to the data from the all-Russia representative survey conducted in the spring of 2015 by the Centre for Social Forecasting and Marketing, today $60,9 \%$ of students are content to live and work in Russia. A small minority of them are planning to leave for former Soviet countries, 15\% intend on going to economically developed countries and 15\% have not yet decided where to go for gainful employment.

The survey has shown that after the collapse of the Soviet Union the migratory intentions of future physicists, mathematicians and engineers that have lost job opportunities in the Russian labour market (in contrast with professionals in financial, economic and legal fields) began increasing in scale with practical steps for going abroad being "realized". More than half of students with serious departure intentions have already had contact with foreign universities and companies, addressed international foundations, passed exams and tests or waited for invitations from relatives or friends from abroad, i.e. took concrete steps to leave Russia (Ledeneva, 1994, p. 37).

According to estimations from the Institute for Economic Forecasts of the Russian Academy of Sciences, in the middle of the 1990s 13000 Russian students were studying abroad full-time in universities of 33 different countries (according to our estimations, in 1995-1996 more than 20000 Russian students were studying abroad). Most young Russians were studying in the US (up to 40\%) with almost the same number (40\%) attending universities and institutions in Germany, France and the UK (Ledeneva, 2002, p.43).

As the survey conducted in spring of 2015 by the Centre for Social Forecasting and Marketing has shown, the migratory intentions of students are not influenced by whether they study at public or their own expense. Thus, of those who want to work in Russia $62,2 \%$ of those studying at public expense and $57,4 \%$ of those who pay for they studies themselves.

The intentions of going to work abroad are mostly widespread among students of medical, agricultural, engineering, economic and the humanities departments (see fig. 7).

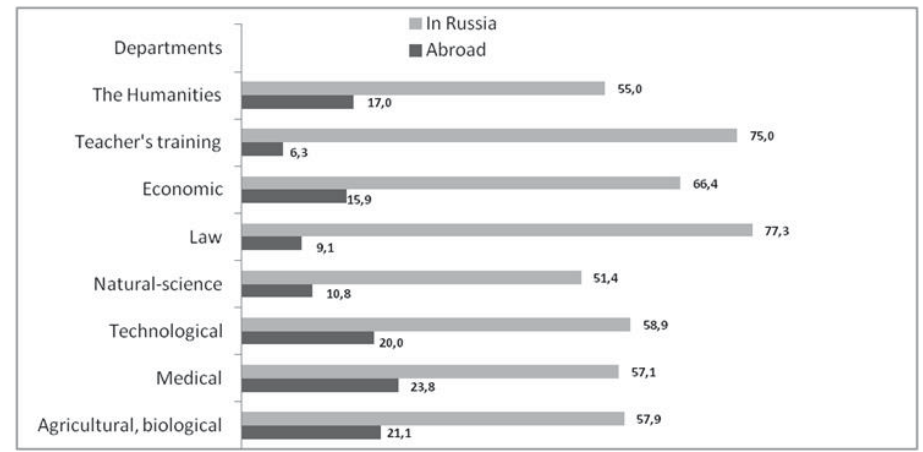

Figure 7 - Percentage of students from different departments who intend working in Russia and abroad. (The shortfall in the overall percentage is made up of those who were either unsure or failed to respond)

\section{Discussion and Conclusions}

The emigration intentions of students are a negative and detrimental phenomenon for Russia. It means the loss of personnel and often a loss of the most talented. The low prestige value of scientific work causes damage which will become apparent in the future when material production will revive and specialists capable of developing new technologies will be required.

For the time being we are restricted to discussing not so much the training of personnel for the Russian science sector as about training intellectuals for export and doing this gratuitously.

University students intent on going to Germany, the US, Canada, France, Australia (see fig. 8). 


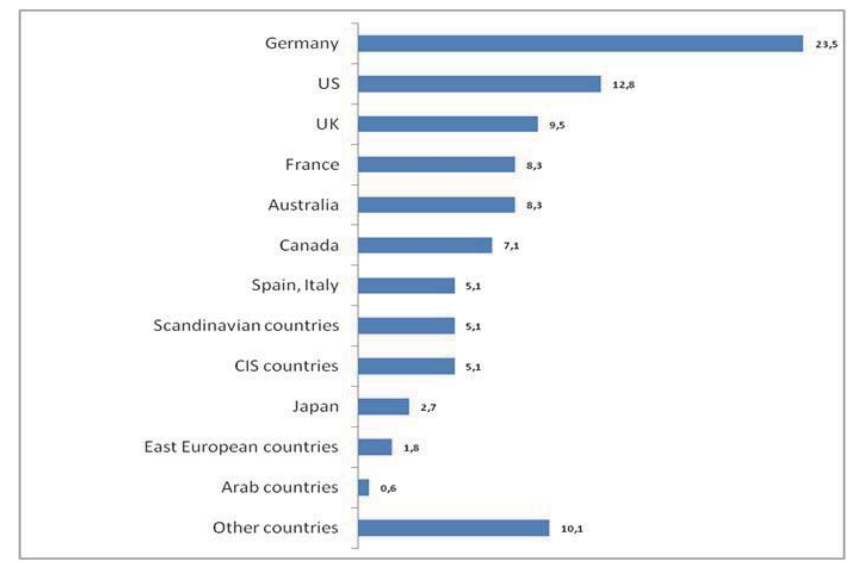

Figure 8 - Proposed countries students intend going to for employment, \%, (16.7\% of those planning to go have been taken from the $100 \%$ total).

Six countries have the opportunity to "pick up" approximately $70 \%$ of Russian students that intend going abroad for employment after graduation. Moreover, $24.8 \%$ of students think that they have acquired, in Russian universities, enough knowledge to work successfully abroad.

Often the decision to emigrate is made by those Russians already studying abroad. These are members of the young Russian elite: half of whom have completed a Russia higher education course and one in ten has completed a post-graduate course without presenting a thesis. Around half of the Russians studying in US universities are Muscovites. Natives of St. Petersburg and regional towns usually prefer European universities. The authors of the study where these figures were presented (Dezhina, 2006) concluded that most Russian students and postgraduates abroad, as well as young professionals working there on contracts, have shaped a stable negative attitude towards Russia as a place of permanent residence and a more positive attitude towards Russia as a place to apply knowledge acquired abroad. So there exists the considerable potential of "intellectual return" to Russia in the form of ideas and professional skills by those highly qualified emigrants who do not want to return but do not exclude, in the future, some form of professional cooperation with their homeland. According to the modern theory regarding the globalization of intellectual resources, the return of ideas has no less importance for the development of scientific and technological potential of the donor country than the physical return of people. With all its attractiveness this conclusion is somewhat naïve, ${ }^{3}$ because in economically developed countries a high level of intellect is well paid by corporations, and technological products created through intellectual resources are patented or kept secret. This highlights intellect as a commodity and is purchased without the right of "resale".

The above analysis does not give grounds for optimistic conclusions. Among university students, as well as among high school students, there are many of those who plan, in the future, to leave the country and work abroad. The reason is a severe lack of prospects in respect to quality of life. To put it simpler, in Russia it is easier to earn one's living by repairing cars than by doing scientific work.

Foreign contracts for Russian postgraduates during their study time are relatively limited. Thus, only $12.5 \%$ of postgraduates surveyed in the spring of 2015 departed abroad, including those who left for scientific probation (8.9\%) and for independent work (3.6\%). Most often postgraduates who departed for probation were specializing in law and for independed work most postgraduates specialized in social sciences.

Today, $61.3 \%$ of surveyed postgraduates intend working in Russia after completing postgraduates courses, $16,7 \%$ intend going to western countries and $22 \%$ have not yet decided but keep this option in their minds. Naturally, none of those surveyed, intend going to the former Soviet countries. The main destinations are Germany, the UK, France, the US and Canada (see fig. 9).

${ }^{3}$ The study in question was conducted at the request of the US and was funded through the Macarthur Foundation. This is why the conclusion about the potential usefulness of intellectual migration for Russia is acceptable primarily for the customer. 


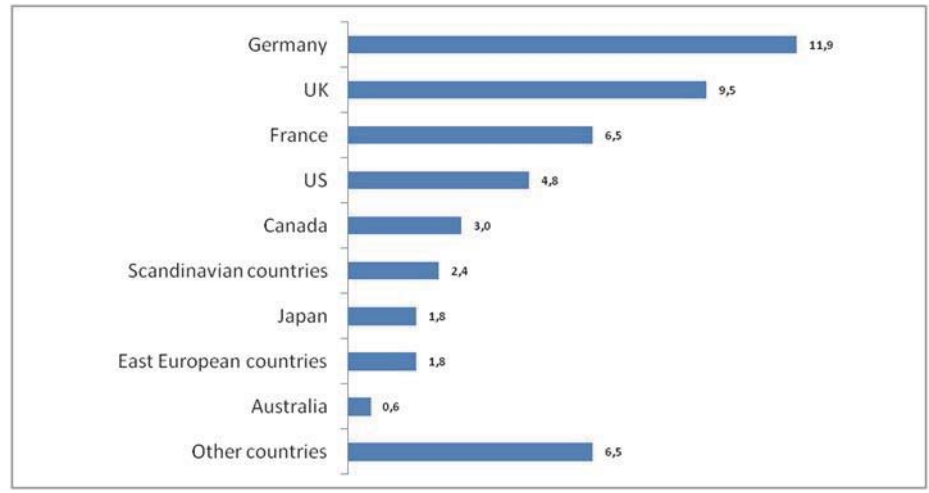

Figure $9-\ln$ which countries postgraduates intend going to for employment in the future, $\%$

The above empirical data show that in spite of increased governmental support for science many young researchers and especially the most talented ones aspire to work in economically developed countries. The reason for this is not only low local salaries but to a lesser extent the protracted rotation of scientific personnel caused by the archaic form of recognizing scientific merits and the use of degree certificates as guarantees for life-long jobs. This rotation mechanism excessively slows down the career self-assertion of young professionals and prevents them from gaining acceptable income and improving their overall quality of life. To a greater extent young researchers are urged to emigrate due to the poor technical and technological infrastructure of research organizations and insufficient involvement in international scientific communication. To create favourable working conditions for Russian researchers current governmental allocations are not enough; what is needed is a considerable rise in demand for scientific production on the part of industry, as well as the creation of non-governmental foundations for supporting science at the expense of the profits of economic monopolies.

\section{Acknowledgments}

This article has been prepared on the basis of an analytical research that has been fulfilled according to the Funding Agreement with the Ministry of Science and Education of the Russian Federation № 03.573.21.0004 from 22 September, 2014. (Code «2014-03-573-0029-002»).

\section{References}

Allakhverdyan, A.G., Agamova, N.S, Ignateva, O.A. (1995). Reverse "Brain Drain" in Russia. Sociological Studies. 12. 68-70. (In Russian).

Arefiev, A.L. (2006) The Activity of Foreign Foundations. Educational and Research Organizations in Russia. Moscow: Center for Social Forecasting and Marketing. (In Russian).

Dezhina, I.G. (2002) "Brain drain" of Post-Soviet Russia: the Evolution of the Phenomenon and its Assessment. Naukovedenie. 3. 25-56. (In Russian).

Dezhina, I. G. (2006). Evolution of state personnel policy in the field of science. Economy and Society. 9. 173-187. (In Russian).

Estimated population of the Russian Federation up to 2030 (2014). Statistical Bulletin. Moscow: Federal State Statistics Service. (In Russian).

Gorshkov, M.K., Sheregi, F.E. (2010) Youth of Russia: Sociological Portrait. Moscow: Center for Social Forecasting and Marketing (in Russian).

Ikonnikova, O.A. (1993).Personnel Emigration from Russia: Today and Tomorrow. Moscow: Compass. (In Russian).

Indicators of Science: 2014 (2014). Moscow: National Research University - Higher School of Economics. (In Russian).

Inglehart, R.F., Ponarin, E.D., Ravlyk M.V. (2014) Regression Models in the Evaluation of International Migration Factors. Sociological Studies. 11. 22-31. (in Russian).

Kelle, V.Zh., Worldly, E.Z, Kugel, S.A., Davidyuk, S.F. (1995). Social Dynamics of Modern Science. Moscow: Nauka. (In Russian).

Ledeneva, L.I. (1994). Emigration intentions of students in big cities of the European part of Russia and the Ukraine. High School in the Mirror of Sociology. 1. 35-40. (In Russian).

Ledeneva, L.I. (2002). Studying abroad as a form of emigration for young Russian people. Herald of Scientific Information. Reforms of 
Yesterday, Today and Tomorrow. 2. 36- 64. (In Russian).

Nikipelova, E.F. (1998) Emigration and Professional Activities of Russian Scientists Abroad. Moscow: CSRS. (In Russian).

OECD (2014). Education at a Glance 2014: OECD Indicators. OECD Publishing. http://dx.doi.org/10.1787/eag-2014-en

Population of the Russian Federation by Sex and Age on 1 January 2013 (2014). Statistical Bulletin. Moscow: Federal State Statistics Service. (In Russian).

Reproduction of the Scientific Elite in Russia: the Role of Foreign Scientific Funds: the Case of Humboldt fund (2005). Edited by A.J. Chepurenko, L.M. Hochberg. Moscow.: RNISiPN. (In Russian).

Science and Engineering Indicators 2010 (2010). Arlington: National Science Foundation.

Shapovalova, A. (2014) Experts: Emigration from Russia reached the scale of 1917 [Online]. Available: http://talia-ru.com. December 24. (In Russian).

Sheregi, F.E., Konstantinovsky D.L., Arefiev A.L. (2006).Russian Universities Collaboration with nternational Foundations and Organizations. Moscow: Center for Social Forecasting. (in Russian).

Student Mobility in Higher Education Among APEC Member Economies (2015). Assessing the Current State of Data and Processes. New York: Institute of International Education.

Transformation of Migration Processes in the Former Soviet Union (2009). Ed. by L.L. Rybakovskii. Moscow: Institute of Socio-Political Research. (In Russian).

Ushkalov, I.G., Malakhov, I.A. (2000) "Brain drain" as a global phenomenon and its peculiarities in Russia. Sociological studies. 3. 110117. (In Russian).

Veryovkin, L.P. (2003) Intellectual Migration: Leave or Stay. Education and Science in the Reforming Process: Sociological Analysis. Moscow: Center for Social Forecasting and Marketing. 300-310. (In Russian).

Yurevich, A.V., Tsapenko, I.P. Intellectual Emigration from Russia. Herald of the Russian Academy of Sciences. Vol. 68. 7. $643-648$. (In Russian).

Zayonchkovskaya, J.A. (2004). Labour Emigration of Russian Scientists. Problems of Forecasting. 4. 98-108. (In Russian).

Zharenova, O.A., Kechil, N.V., Pakhomov, E.Y. (2002). Intellectual Migration of Russians. Neighbouring Countries and Beyond. Moscow: GNOMiD. (In Russian). 